\title{
TITLE:
}

\section{Effect of ProNectin F derivatives on cell attachment and proliferation.}

$\operatorname{AUTHOR}(\mathrm{S})$ :

Somamoto, Satoshi; Tabata, Yasuhiko

\section{CITATION:}

Somamoto, Satoshi ...[et al]. Effect of ProNectin F derivatives on cell attachment and proliferation.. Acta biomaterialia 2013, 9(2): 5194-5200

ISSUE DATE:

2013-02

URL:

http://hdl.handle.net/2433/169707

\section{RIGHT:}

(c) 2012 Acta Materialia Inc. Published by Elsevier Ltd.; This is not the published version. Please cite only the published version.; この論文は 出版社版でありません。引用の際には出版社版をご確認ご利用くださ い。 
Effect of ProNectin F derivatives on cell attachment and proliferation SATOSHI SOMAMOTO ${ }^{1,2}$ and YASUHIKO TABATA ${ }^{1}$

Short / Running Title: Cellular effects of ProNectin F derivatives

${ }^{1}$ Department of Biomaterials, Institute for Frontier Medical Sciences, Kyoto University,

53 Kawara-cho Shogoin, Sakyo-ku Kyoto 606-8507, Japan

${ }^{2}$ Sanyo Chemicallindustries Ltd.,

1-40, Goryo Ohara, Nishikyo-ku, Kyoto 615-8245, Japan

TEL $+81-75-751-4121$

FAX $+81-75-751-4646$

E-mail: yasuhiko@frontier.kyoto-u.ac.jp 


\section{Abstract}

ProNectin F (PnF) was chemically modified by introducing some functional groups to prepare various derivatives of primary amino (PnF-N1), tertiary amino (PnF-N3), quaternary ammonium (PnF-N4), carboxyl (PnF-COOH), and sulfonyl groups $\left(\mathrm{PnF}_{-} \mathrm{SO}{ }_{3} \mathrm{H}\right)$ introduction. When $\mathrm{C} 3 \mathrm{H} 10 \mathrm{~T} 1 / 2$ cells were cultured on non-treated dishes coated with the derivatives, the number of mesenchymal cells attached onto culture dishes increased for the coating with $\mathrm{PnF}-\mathrm{COOH}$ and $\mathrm{PnF}_{-} \mathrm{SO}_{3} \mathrm{H}$ even at their low adsorption amount. The cytotoxicity was high for the coating of PnF-N1 and PnF-N4 compared with that of the PnF-N3, PnF-COOH, and PnF-SO 3 H. The treatment with integrin $\alpha 5$ and $\alpha \mathrm{V}$ antibodies suppressed the cell attachment onto the dishes coated with PnF-COOH and $\mathrm{PnF}-\mathrm{SO}_{3} \mathrm{H}$. The phosphorylation of extracellular signal-regulated kinase (ERK) was upregulated for cells attached onto the dishes coated with PnF-COOH and $\mathrm{PnF}-\mathrm{SO}_{3} \mathrm{H}$, indicating their enhanced proliferation. It is concluded that the chemical derivatization of PnF enhanced the ability of cell attachment and proliferation.

Keywords: ProNectin F, artificial protein, cell adhesion, proliferation, integrin 


\section{Introduction}

ProNectin $\mathrm{F}(\mathrm{PnF})$ is an artificial protein of 980 amino acids commercially available [1, 2]. It contains a repeated peptide segment of GAGAGS originated from silk fibroin, and GAAVTGRGDSPASAAGY from fibronectin

[3]. This segment is repeated 13 times on one molecule of PnF. The protein is resistant to heat, biologically stable for several months at room temperature, highly water-soluble, and adsorbable to the hydrophobic surface of polystyrene even in the presence of water. PnF can be autoclaved at $121^{\circ} \mathrm{C}$ without any loss of cell adhesive activity [4].

Interaction of extracellular matrix (ECM) proteins and integrin receptors of cells is required for the survival of anchorage-dependent cells [5]. In anchorage-dependent cells, the interactions activate various intracellular signaling pathways that play an important role in the cell viability, proliferation, and differentiation [6, 7]. Integrins are members of a widely expressed family of heterodimeric transmembrane receptors that bind to cell adhesive motifs present in various ECM proteins including fibronectin, vitronectin, laminin, and collagen [6, 8] . It's known that the ECM interaction through the integrin of cells contribute to their survival and their apoptosis suppression [5, 9-11].

Therefore, ECM proteins have been used to manipulate the cell behavior. PnF with integrin ligand sequences have been developed as a substitute of natural ECM proteins [4, 12-15].

The surface properties of biomaterials play critical roles in cell behaviors. It has been demonstrated that the type, quantity, and activity of proteins adsorbed on cell substrates are influenced by the physicochemical properties, such as the charge and hydrophobicity [16-19]. Various cellular responses were observed for substrates with different surfaces [20]. The surface property of substrates modifies the functional presentation of major integrin binding 
domain of fibronectin, and consequently alters the integrin binding to potentiate the extent of cell attachment [21].

Fundamentally, cell-ECM interaction is composed of the interaction between the ligand of ECM and the receptor of cell surface. The interaction is based on various physicochemical interactions of coulombic and hydrophobic forces in the molecular level. PnF contains 13 arginine-glycine-aspartic acid (RGD) sequences of a cell adhesion motif which contains in the ECM [4]. The sequence mainly contributes to the cell interaction of PnF. The objective of this study is to obtain the fundamental knowledge whether or not the chemical derivatization of PnF can modify the manner of cell interaction. PnF was chemically derivatized by the introduction of cationic and anionic functional groups. Cells were cultured on the dishes coated with $\mathrm{PnF}$ and the derivatives to evaluate the coating effect on the attachment and proliferation of cells. We examine the conformation change of PnF through the chemical derivatization.

\section{Materials and Methods}

\subsection{Materials}

ProNectin F (Lot \#:100630) was kindly supplied from Sanyo Chemical Industries, Kyoto, Japan. Other chemicals were obtained from Wako Pure Chemical Industries, Ltd., Osaka, Japan and used without further purification.

\subsection{Chemical modification of ProNectin $F$ and conformational characterization}


The chemical modification of ProNectin F was performed according to the method previously reported with partial modification [22]. ProNectin F $(0.5 \mu \mathrm{mol})$ was dissolved in $0.5 \mathrm{ml}$ of $4.5 \mathrm{M}$ lithium perchlorate in water. 2-Chloroethyl amino hydrochloride (1.5 mmol), 2-chloroethyl-N,N-dimethyl ammonium chloride (1.5 mmol), (2-chloroethyl) trimethyl ammonium chloride $(1.5 \mathrm{mmol})$, chloroacetic acid $(1.5 \mathrm{mmol})$, or 2-chloroethanesulfonic acid sodium salt $(1.5 \mathrm{mmol})$ was dissolved in $0.5 \mathrm{ml}$ of $4.5 \mathrm{M}$ lithium perchlorate solution, and each solution was added into the mixture with stirring at room temperature for the chemical derivatization of primary amino, tertiary amino, quaternary ammonium, carboxyl, and sulfonyl groups, respectively. Aqueous solution of $4.5 \mathrm{M}$ lithium perchlorate $(0.4 \mathrm{ml})$ containing $0.8 \mathrm{mmol}$ of $\mathrm{NaOH}(2.0 \mathrm{M})$ was added into the mixture, followed by stirring at room temperature for $24 \mathrm{hr}$. The reaction was stopped by the neutralization of solution at $\mathrm{pH}$ 6.5-6.8 by adding glacial acetic acid. Then, the mixture was dialyzed for $24 \mathrm{hr}$ against double-distilled deionized water (DDW) using a dialysis membrane (the cutoff molecular weight.6000-8000, Spectrum Laboratories, Inc., Rancho Dominguez, CA, USA) and the content of dialysis bag was frozen and lyophilized.

The percentage of functional groups introduced was determined by the decrease of serine. The percent introduced was calculated based on the percent decrease in the $\mathrm{OH}$ groups of serine before and after the reaction according to the amino acid analysis. The samples were solubilized in DDW and measured at $25^{\circ} \mathrm{C}$ on a Circular dichroism (CD) Jasco J-820 spectropolarimeter (Jasco ltd., Tokyo, Japan) in a cell with a $0.1 \mathrm{~cm}$ path length. The comformational content was calculated by using a reference spectrum according to the procedure reported [23]. 


\subsection{Preparation of polystyrene dishes coated with different amounts of PnF and the derivatives}

The solution of $\mathrm{PnF}$ and the derivatives $(50 \mu \mathrm{l})$ in $10 \mathrm{mM}$ phosphate-buffered saline (PBS, pH 7.4) was added into each well of 96-well multi-well untreated polystyrene plates $(7.15 \mathrm{~mm}$ in diameter, Cat. No. 1860-096, Asahi Glass Co., Ltd, Tokyo, Japan) and incubated for $2 \mathrm{hr}$ at $37^{\circ} \mathrm{C}$. The solution was removed, and each well was washed twice with PBS. The amount of protein adsorbed was measured with a Micro BCA protein assay kit (Thermo Fisher Scientific Inc., Waltham, MA). Next, $0.05 \mathrm{wt} \%$ bovine serum albumin (BSA) solution in PBS was added into each well and incubated for $2 \mathrm{hr}$ at $37{ }^{\circ} \mathrm{C}$. The BSA solution was removed, and the well was washed twice with PBS to use as polystyrene dishes coated. Experiments were performed independently three times and the mean value is shown as the amount of adsorption.

\subsection{Cells culture}

A cell line of mesenchymal cells (C3H10T1/2) was used and cultured in Dulbecco's Modified Eagle's medium (DMEM, Gibco Lifetechnologies Co., Carlsbad, CA) supplemented with $10 \mathrm{wt} \%$ fetal bovine serum (FBS) (Gibco Lifetechnologies Co., Carlsbad, CA) and $1 \mathrm{wt} \%$ of both penicillin and streptomycin (Sigma-Aldrich Co., St. Louis, $\mathrm{MO}$ ) at a humidified $5 \% \mathrm{CO}_{2}-95 \%$ air atmosphere at $37^{\circ} \mathrm{C}$. Cells were detached from dishes by the treatment of trypsin- ethylenediaminotetraacetate (EDTA) solution (Sigma-Aldrich Co., St. Louis, MO) and used for the following cell culture experiments.

\subsection{Cell attachment assay}


Cell attachment was evaluated according to the method reported previously [24]. Cells proliferated were washed twice with FBS-free DMEM to remove cell adhesive factors from the serum. The cell suspension in FBS-free DMEM $\left(2.0 \times 10^{4}\right.$ cells, $\left.100 \mu \mathrm{l}\right)$ was added to PnF-, PnF derivatives-, fibronectin- or collagen-coated dishes, and cultured for $2 \mathrm{hr}$ at $37{ }^{\circ} \mathrm{C}$. Non-adhesive cells were removed by washing with FBS-free DMEM, and a cell-counting reagent (Cell count Reagent SF, Nacalai Tesque Co., Ltd, Kyoto, Japan) was added to each well. After incubation with the reagent for $2 \mathrm{hr}$, the absorbance of each well was measured using a UV-microplate reader (VERSA max, Molecular Devices Inc, Sunnyvale, CA) at $562 \mathrm{~nm}$. The number of cells attached was calculated with a standard curve prepared by titrating the known number of cells.

\subsection{Cytotoxicity assay}

The cytotoxicity of PnF and PnF derivatives was examined by measuring the leakage of cell membrane with lactate dehydrogenase (LDH) [25]. After incubation of cells for $1 \mathrm{hr}$ in the presence of PnF and PnF derivatives, the amount of LDH leaked from cells was measured with LDH-cytotoxic test Wako (Wako Pure Chemical Industries, Ltd., Osaka, Japan). The present cytotoxicity was calculated by dividing the amount of LDH leakage in PnF and PnF derivatives by that of the positive control group of $0.2 \mathrm{wt} \%$ Tween 20 treatment and the negative control PBS group, while the cell number was fixed at $1.0 \times 10^{4}$ cells.

\subsection{Proliferation assay}


Cell proliferation was evaluated according to the method reported previously [24]. Cells proliferated were washed twice with FBS-free DMEM to remove cell adhesive factors from the serum. The cell suspension in FBS-free DMEM $\left(2.0 \times 10^{3}\right.$ cells, $\left.100 \mu \mathrm{l}\right)$ was added to PnF-, PnF derivatives-, fibronectin- or collagen-coated dishes, and cultured for 1 day. Then, the medium was changed to the DMEM containing 0.1 vol\% FBS. Cells cultured for 5, 12, and 15 days. The cell-counting reagent was added to each well. After $2 \mathrm{hr}$ of incubation with the reagent, the absorbance of each well measured using a UV-microplate reader at $562 \mathrm{~nm}$. The number of cells was calculated with a standard curve prepared by titrating the known number of cells with the same cell counting method. The number of cells was defined as that of cells proliferated for 5,12 , and 15 days.

\subsection{Blocking assay by integrin antibodies}

To evaluate the effect of integrin receptors on the attachment of cells, the blocking assay was performed.

Cells proliferated were washed twice with FBS-free DMEM, and then cells washed were treated with $5 \mu \mathrm{g} / \mathrm{ml}$ anti-integrin- $\alpha 2$ and $-\alpha \mathrm{V}$ antibodies (Millipore InC., Billerica, MA), $5 \mu \mathrm{g} / \mathrm{ml}$ anti-integrin- $\alpha 3$ antibodies(Chemicon Inc., Temecula, CA), $5 \mu \mathrm{g} / \mathrm{ml}$ anti-integrin- $\alpha 4$ and $-\alpha 6$ antibodies (R\&D Inc., Minneapolis, MN), or $5 \mu \mathrm{g} / \mathrm{ml}$ anti-integrin- $\alpha 5$ antibodies (Abcam Plc., Cambridge, UK) for 30 min at $37{ }^{\circ} \mathrm{C}$. Next, the cells were centrifuged at 1,000 rpm for $5 \mathrm{~min}$ at room temperature, and the cell pellet was resuspended in FBS-free DMEM. Then, the cell attacment assay was performed as described above. 


\subsection{Estimation of ERK phosphorylation}

Cells were cultured on PnF-, PnF derivatives-, fibronectin- or collagen-coated dishes for $2 \mathrm{hr}$. The cells were treated with a lysis buffer $(50 \mathrm{mmole} / \mathrm{l}$ Tris- $\mathrm{HCl}, 150 \mathrm{mmole} / \mathrm{l} \mathrm{NaCl}, 1 \mathrm{mmole} / \mathrm{l}$ ethylenediaminotetraacetate (EDTA), 0.1wt\% Nonidet P-40 ; pH 7.4) containing a protease inhibitor mixture (Cat. No. P8340, Sigma-Aldrich Co., St. Louis, MO) for cell lysation. The protein content of cell lysates was measured with a Micro BCA protein assay kit. The cell lysates prepared were applied to sodium dodecylsulfate polyacrylamide electrophoresis (SDS-PAGE) and transferred to an Immobilon-P membrane (Millipore Inc., Milford, MA). $15 \%$ SDS-PAGE gel was used and $50 \mu \mathrm{g}$ of proteins were applied to each lane. The membrane was immunoblotted with an antibody against phospho-ERK or ERK (Lot No. 23 and 16, Cell Signaling Technology Inc., Beverly, MA) and $\beta$-actin (Sigma-Aldrich Co., St. Louis, MO) as an internal control as the diluted ratios of 1:1000, 1:1000, and 1:5000, respectively. After incubation with a peroxidase-conjugated anti-mouse or anti-rabbit secondary antibody (Lot. No. FK928983 or LB142282, Sigma-Aldrich Co., St. Louis, MO), the target proteins were immunologically visualized with SuperSignal West Pico Chemiluminescent Substrate (Lot. No. LF144837, Pierce, Thermo Fisher Scientific, Rockford, IL). The westernblot gel image was analyzed by image $\mathbf{J}$ (National Institutes of Health, Bethesda, MD). The band intensity was normalized by cell culture dish (95 well cell culture cluster, Cat. No. 3595, Corning Inc., One Riverfront Plaza, NY).

\subsection{Statistical analysis}

All the results were statistically analyzed by Tukey-Kramer test and $p<0.05$ was considered to be 
statistically significant. Data were expressed as the mean \pm the standard deviation. Experiments were replicated independently three times unless otherwise mentioned.

\section{Results}

\subsection{Chemical modification of PnF}

Primary amino, tertiary amino, and quaternary ammonium groups were introduced to $\mathrm{PnF}$ as cationic functional groups. Carboxyl, and sulfonyl groups were also introduced to $\mathrm{PnF}$ as anionic functional groups. Figure 1 shows the percent introduction of functional groups as a function of reaction time. The percent introduction increased with time of reaction, irrespective of the type of functional groups.

Figure 2 shows the CD spectra of PnF derivatives. Table 1 shows the percentage of functional groups introduced and the conformation of PnF derivatives. The conformation of PnF derivatives changed with an increase in the amount of chemical residues in a similar fashion, irrespective of the residues type (data not shown). When the functional groups were introduced around $15 \mathrm{~mol} \%$ of $\mathrm{PnF} \mathrm{OH}$, the $\beta$-sheet structure was collapsed, and then converted to the randomcoil one.

\subsection{Cell attachment onto PnF or the derivatives-coated dishes}

Figures 3A and 3B show cells attachment to PnF or the dishes coated with different adsorption concentrations of PnF and the derivatives. Figure 3A shows cells attachment as a function of the amount of PnF 
derivatives adsorbed on surface. Figure 3B shows cells attachment to PnF derivatives at low protein adsorption

amount. To evaluate the initial cell attachment to the PnF, non-adhesive cells were excluded $2 \mathrm{hr}$ after incubation. At a high amount of PnF adsorbed, a constant number of cells attached was observed for the PnF-N3-coated dishes. At a low amount of adsorption, significantly high cell number was observed for PnF-N3, PnF-COOH, and the PnF-SO3H-coated dishes. On the contrary, the coating of PnF-N1 and PnF-N4 decreased the cell attachment at a high amount of protein adsorbed. Figures $\mathbf{3 C}$ shows the morphology of cells attached on the dishes coated with PnF and the derivatives. The shape of cells cultured on the PnF-, PnF derivatives-, fibronectin-, and collagen-coated dishes was similarly spread while adhered.

\subsection{Effect of PnF modification rate on cell attachment}

Figure 4 shows the cell attachment onto dishes coated with $\mathrm{PnF}$ derivatives with different introduction percentages. The introduction percentage was determined by the decrease of serine hydroxyl groups before and after the reaction according to the amino acid analysis. The number of attached cells decreased with an increase in the introduction percentages. However, the PnF-N3, PnF-COOH, and PnF-SO3H coating did not decrease the cell attachment.

Figure 5 shows the LDH activity of cells cultured in the medium containing PnF derivatives. The coating concentration is $10 \mu \mathrm{g} / \mathrm{ml}$. The LDH activity increased with an increase in the concentration. The LDH activity increased for cells cultured on the dishes coated with PnF-N1 and PnF-N4. On the contrary, the LDH activity was 
suppressed for cells cultured on the PnF-N3, PnF-COOH, and PnF-SO3H-coated dishes.

\subsection{Effect of functional groups on the cell adhesion manner}

Table 2 shows the percent decrease in the number of cells attached after the treatment with antibodies against different integrin $\alpha$ subunits. Figure 6 shows the effect of integrin antibody treatment on the cell attachment onto PnF derivatives-coated dishes. The primary amino, the tertiary amino, and the quaternary ammonium groups tended to increase the association with $\alpha 2$ and $\alpha 6$ integrins when compared the association of PnF. On the contrary, the association with the $\alpha 4$ integrin decreased. The association with the integrin $\alpha \mathrm{V}$ increased by the derivatization of carboxyl and sulfonyl groups.

Figure 7 A shows the ERK phosphorylation of cells cultured on dishes coated with PnF and the derivatives $2 \mathrm{hr}$ after incubation. Figure $7 \mathrm{~B}$ shows the westernblotting image of ERK phosphorylation of cells cultured. The band density was normalized by that of cells cultured on the original culture dish. The significant increase of ERK phosphorylation was observed for cells cultured on PnF-COOH- and PnF-SO3H-coated dishes compared with that of PnF-coated one. On the contrary, the PnF-N1, PnF-N3, and PnF-N4 coating had no influence.

\subsection{Proliferation of cells cultured on dishes coated with PnF and the derivatives}

Figure 8 shows the number of cells after culturing on dishes coated with PnF and the derivatives. The number of cells was counted after 5, 12, and 15 days after incubation. After 15 days culture, cells cultured on the dish 
coated with the original PnF reached at the 80 90\% confluence. The number of cells cultured on fibronectin- and collage-coated dishes slightly increased in a low serum condition. On the other hand, the number of cells cultured on PnF derivatives-coated dishes increased to a significantly higher extent. The significant increase in the cell number was observed on PnF-COOH- and PnF-SO3H-coated dishes compared with that of PnF-coated one. On the contrary, the PnF-N1 coating decreased the cell number although the PnF-N3 and PnF-N4 coating had no influence.

\section{Discussion}

The present study demonstrated that the effect of chemical modification of PnF affects the cell attachment and proliferation. The serine content of $\mathrm{PnF}$ decreased with time when determined by the amino acid analysis (Figure 1). This indicates that PnF was chemically modified by introducing different functional groups. The PnF derivatization lost the $\beta$-sheet structure of original $\mathrm{PnF}$ and brought about a random coil structure (Figure 2). It is reported that the chemical modification by the amino, carboxyl, and sulfonyl groups allows silk fibroin to have a random coil conformation [27]. It is highly conceivable that this conformational change causes change in the affinity of RGD sequences to bind to the integrin of cells.

It has been reported that some types of cells (fibroblast and endothelial cells) attached onto PnF- and PnF-N3-coated dishes in FBS-free condition. The cells attached onto the PnF- and PnF-N3-coated dishes to a greater extent than fibronectin-coated dishes [30, 31]. The similar result was obtained in this study. In addition, cells attached much more onto PnF-COOH- and PnF-SO3H-coated dishes. The number of cells attached on dishes coated with 
PnF-N3, PnF-COOH, and PnF-SO3H increased even at the low amount of protein adsorbed (Figure 3). There are various plausible reasons to change the interaction manner of PnF derivatives and integrins. Among them, the phenomenon can be explained in terms of change in the interaction manner. It is possible that the chemical modification with positive and negative residues causes the changes in overall conformation of PnF as well as changing the receptor-ligand affinity between PnF and integrins. For the dishes coated with PnF-N1 and PnF-N4, however, the number of cells attached did not increase and decreased with an increase in the percent introduction (Figures 3 and 4). It is recognized that the water wettability of substrate surface linearly increased with the increasing carboxyl group content of collagen and no cytotoxicity was detected [32]. A good correlation between the number of positive charges on the protein surface and the cytotoxic activity is demonstrated [33, 34]. The basicity of amino groups in water is in the order of the secondary $>$ the primary $>$ the quaternary $>$ the tertiary, because of the hydration extent [35]. In the case of cationized PnF, the cytotoxicity of positive charges from the primary and quaternary amino groups resulted in the decrease of cells attachment while the tertiary amino group showed no cytotoxicity (Figure 5). It is conceivable that the lowest basicity of the tertiary group resulted in the low cytotoxity. As a result, the number of cell attachment onto PnF-N3-coated dishes was larger than PnF-N1- and PnF-N4-coated dishes.

It is known that the integrin $\alpha \mathrm{V}$ has a wide association with various ECMs with the positive amino block of RGD and GRKRK $[36,37]$. Therefore, it is possible that the carboxyl and sulfate groups of negative charge are likely to adsorb positive charge substances, resulting in enhanced association with the $\alpha \mathrm{V}$ integrin. Figure 6 showed that the 
treatment of integrin $\alpha 5$ and $\alpha \mathrm{V}$ antibodies suppressed the cell attachment on the dishes coated anionic groups-introduced PnF. It is well recognized that the $\alpha$-subunit of integrins associate with particular trans membrane and cytoplasmic proteins to specifically activate the intracellular signaling pathways [38]. Caveolin-1 links the integrin $\alpha 1, \alpha 5$, and $\alpha \mathrm{V}$ binding to the Src pathway that plays a key role in the promotion of cell proliferation through the phosphorylation of ERK [39]. Integrins $\alpha 5$ and $\alpha \mathrm{V}$ which modulate the cell proliferation, interacted with the PnF-COOH and PnF-SO3H (Figure 6). It is known that fibronectin has an affinity for many types of integrins [26]. In this study, fibronectin mainly bound to integrins $\alpha 4$ and $\alpha 6$, but the reason is unclear at present. In addition, the phosphorylation of ERK was increased (Figure 7). It is possible that for the carboxyl and sulfonyl groups-coated dishes, the enhanced ERK phosphorylation resulted in the promoted cell proliferation (Figure 8). It is concluded that the chemical modification of PnF with the tertiary amino, carboxyl, and sulfonyl groups was promising to enhance the cell attachment and the subsequent proliferation. The design of cell culture substrate is important to manipulate the proliferation and differentiation of cells in terms of regenerative medicine where the cellular potential can be artificially enhanced for cell-based therapy. Based on the results obtained, the ProNectin and the derivatives may be promising as a coating material which makes the substrate surface cytocompatible to modify the cell behavior. The cell line of $\mathrm{C} 3 \mathrm{H} 10 \mathrm{~T} 1 / 2$ was used in this study as a stem cell with high potential of proliferation and differentiation. The effect of ProNectin derivatives on the cell differentiation will be reported in the future.

\section{Conclusions}


PnF was chemically modified by the primary, tertiary amino, quaternary ammonium, carboxyl, and sulfonyl groups. The cytotoxicity was low for PnF-N3, PnF-COOH, and PnF-SO3H. The number of cells attached onto the dishes coated with PnF-N3, PnF-COOH, and PnF-SO3H was higher than that of original PnF. In addition, the phosphorylation of ERK was upregulated for cells attached onto the dishes coated with PnF-COOH and $\mathrm{PnF}-\mathrm{SO} 3 \mathrm{H}$. Actually, integrin subunits attached PnF-derivatives are changed each derivatives. The derivatization of the tertiary amino, and carboxyl, and sulfonyl groups increase cell attachment and proliferation. 


\section{Reference}

[1] J c. microbial production of structural protein polymers, in: plastics from microbes. carl hanser verlag 1994:34-92.

[2] j c. genetically engineered protein polymers. handbook of biodegradabel polymers 1997:1-32.

[3] DeSimone DW, Stepp MA, Patel RS, Hynes RO. The integrin family of cell surface receptors. Biochem Soc Trans 1987;15:789-91.

[4] Heslot H. Artificial fibrous proteins: a review. Biochimie 1998;80:19-31.

[5] Meredith JE, Jr., Fazeli B, Schwartz MA. The extracellular matrix as a cell survival factor. Mol Biol Cell 1993;4:953-61.

[6] Hynes RO. Integrins: bidirectional, allosteric signaling machines. Cell 2002;110:673-87.

[7] Giancotti FG, Ruoslahti E. Integrin signaling. Science 1999;285:1028-32.

[8] Ruoslahti E, Pierschbacher MD. Arg-Gly-Asp: a versatile cell recognition signal. Cell 1986;44:517-8.

[9] Frisch SM, Screaton RA. Anoikis mechanisms. Curr Opin Cell Biol 2001;13:555-62.

[10] Liddington RC, Ginsberg MH. Integrin activation takes shape. J Cell Biol 2002;158:833-9.

[11] Vuori K. Integrin signaling: tyrosine phosphorylation events in focal adhesions. J Membr Biol 1998;165:191-9.

[12] Hosseinkhani H, Tabata Y. PEGylation enhances tumor targeting of plasmid DNA by an artificial cationized protein with repeated RGD sequences, Pronectin. J Control Release 2004;97:157-71.

[13] Ohyama T, Ko IK, Miura A, Iwata H, Taki W. ProNectin F-grafted-ethylene vinyl alcohol copolymer (EVAL) as a liquid type material for treating cerebral aneurysm--an in vivo and in vitro study. Biomaterials 2004;25:3845-52.

[14] Kurokawa M, Sato S. Growth and poliovirus production of Vero cells on a novel microcarrier with artificial cell adhesive protein under serum-free conditions. J Biosci Bioeng;111:600-4.

[15] Okazaki A, Jo J, Tabata Y. A reverse transfection technology to genetically engineer adult stem cells. Tissue Eng 2007;13:245-51.

[16] McClary KB, Grainger DW. RhoA-induced changes in fibroblasts cultured on organic monolayers. Biomaterials 1999;20:2435-46.

[17] McClary KB, Ugarova T, Grainger DW. Modulating fibroblast adhesion, spreading, and proliferation using self-assembled monolayer films of alkylthiolates on gold. J Biomed Mater Res 2000;50:428-39.

[18] Scotchford CA, Gilmore CP, Cooper E, Leggett GJ, Downes S. Protein adsorption and human osteoblast-like cell attachment and growth on alkylthiol on gold self-assembled monolayers. J Biomed Mater Res 2002;59:84-99. 
[19] Mrksich M, Whitesides GM. Using self-assembled monolayers to understand the interactions of man-made surfaces with proteins and cells. Annu Rev Biophys Biomol Struct 1996;25:55-78.

[20] Allen LT, Fox EJ, Blute I, Kelly ZD, Rochev Y, Keenan AK, et al. Interaction of soft condensed materials with living cells: phenotype/transcriptome correlations for the hydrophobic effect. Proc Natl Acad Sci U S A 2003;100:6331-6.

[21] Keselowsky BG, Collard DM, Garcia AJ. Surface chemistry modulates fibronectin conformation and directs integrin binding and specificity to control cell adhesion. J Biomed Mater Res A 2003;66:247-59.

[22] chemical modification of repetitive polymers to enhance water solubility. United states patent $5,760,0041994$.

[23] Yang JT, Wu CS, Martinez HM. Calculation of protein conformation from circular dichroism. Methods Enzymol 1986;130:208-69.

[24] Kurihara H, Nagamune T. Cell adhesion ability of artificial extracellular matrix proteins containing a long repetitive Arg-Gly-Asp sequence. J Biosci Bioeng 2005;100:82-7.

[25] Yoshida N, Koizumi M, Adachi I, Kawakami J. Inhibition of P-glycoprotein-mediated transport by terpenoids contained in herbal medicines and natural products. Food Chem Toxicol 2006;44:2033-9.

[26] Johansson S, Svineng G, Wennerberg K, Armulik A, Lohikangas L. Fibronectin-integrin interactions. Front Biosci 1997;2:d126-46.

[27] Murphy AR, St John P, Kaplan DL. Modification of silk fibroin using diazonium coupling chemistry and the effects on hMSC proliferation and differentiation. Biomaterials 2008;29:2829-38.

[28] Keselowsky BG, Collard DM, Garcia AJ. Surface chemistry modulates focal adhesion composition and signaling through changes in integrin binding. Biomaterials 2004;25:5947-54.

[29] Lan MA, Gersbach CA, Michael KE, Keselowsky BG, Garcia AJ. Myoblast proliferation and differentiation on fibronectin-coated self assembled monolayers presenting different surface chemistries. Biomaterials 2005;26:4523-31.

[30] Esty A. Receptor-specific serum-free cell attachment using a highly stable engineered protein polymer. Am Biotechnol Lab 1991;9:44.

[31] Ishii-Watabe A, Kanayasu-Toyoda T, Suzuki T, Kobayashi T, Yamaguchi T, Kawanishi T. Influences of the recombinant artificial cell adhesive proteins on the behavior of human umbilical vein endothelial cells in serum-free culture. Biologicals 2007;35:247-57.

[32] Bet MR, Goissis G, Vargas S, Selistre-de-Araujo HS. Cell adhesion and cytotoxicity studies over polyanionic collagen surfaces with variable negative charge and wettability. Biomaterials 2003;24:131-7.

[33] D'Errico G, Ercole C, Lista M, Pizzo E, Falanga A, Galdiero S, et al. Enforcing the positive charge of $\mathrm{N}$-termini enhances membrane interaction and antitumor activity of bovine seminal ribonuclease. Biochim Biophys Acta;1808:3007-15. 
[34] Fischer D, Li Y, Ahlemeyer B, Krieglstein J, Kissel T. In vitro cytotoxicity testing of polycations: influence of polymer structure on cell viability and hemolysis. Biomaterials 2003;24:1121-31.

[35] Nagy P. Theoretical calculations on the basicity of amines. journal of molecular structure 1989;201:271-86.

[36] Akhtar K, Broekelmann TJ, Song H, Turk J, Brett TJ, Mecham RP, et al. Oxidative modifications of the C-terminal domain of tropoelastin prevent cell binding. J Biol Chem;286:13574-82.

[37] Bax DV, Rodgers UR, Bilek MM, Weiss AS. Cell adhesion to tropoelastin is mediated via the C-terminal GRKRK motif and integrin alphaVbeta3. J Biol Chem 2009;284:28616-23.

[38] Giancotti FG. Complexity and specificity of integrin signalling. Nat Cell Biol 2000;2:E13-4.

[39] Wary KK, Mariotti A, Zurzolo C, Giancotti FG. A requirement for caveolin-1 and associated kinase Fyn in integrin signaling and anchorage-dependent cell growth. Cell 1998;94:625-34. 


\section{Figure captions}

Figure 1. The profile of $\mathrm{PnF}$ chemical modification by introduction of different functional

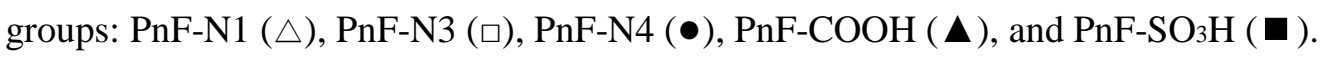

Figure 2. Conformational analysis of $\mathrm{PnF}$ and the derivatives. $\mathrm{CD}$ spectra of $\mathrm{PnF}(\mathrm{O}), \mathrm{PnF}-\mathrm{N} 1$

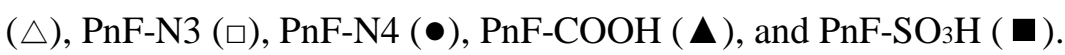

Figure 3. Initial attachment of cells onto culture dishes coated with $\operatorname{PnF}(\circ), \operatorname{PnF}-\mathrm{N} 1(\triangle)$, PnF-N3 ( $\square)$, PnF-N4 $(\bullet)$ PnF-COOH ( $\Delta), \mathrm{PnF}-S O_{3} \mathrm{H}(\boldsymbol{\square})$, fibronectin $(\nabla)$, and collagen $(\boldsymbol{\nabla})$. A Effect of protein adsorption amount on the cell attachment. B Cell attachment at low Protein adsorption amount. The cell attachment was examined $2 \mathrm{hr}$ after incubation. $\mathbf{C}$ The morphology of cells attached on the dishes coated with PnF and the derivatives $2 \mathrm{hr}$ after incubated.

Figure 4. Initial attachment of cells onto dishes coated with PnF-N1 $(\triangle)$, PnF-N3 ( $\square$ ), PnF-N4 $(\bullet), \operatorname{PnF}-\mathrm{COOH}(\boldsymbol{\Delta})$, and $\mathrm{PnF}-\mathrm{SO}_{3} \mathrm{H}(\boldsymbol{\bullet})$.

Figure 5. LDH activity of cells cultured in medium containing PnF-N1 $(\triangle)$, PnF-N3 ( $\square$ ), PnF-N4 $(\bullet), \mathrm{PnF}-\mathrm{COOH}(\boldsymbol{\Delta})$, and $\mathrm{PnF}_{-} \mathrm{SO}_{3} \mathrm{H}$ ). The coating concentration is $10 \mu \mathrm{g} / \mathrm{ml}$. The percent $\mathrm{LDH}$ activity for unmodified $\mathrm{PnF}$ is that at the percent $\mathrm{OH}$ introduced of 0 .

Figure 6. Inhibition patterns of cells attachment onto the dishes coated with $10 \mu \mathrm{g} / \mathrm{ml}$ of PnF, PnF-derivatives, fibronectin, and collagen $2 \mathrm{hr}$ after incubation in the presence of anti-integrin $\alpha 2(\square), \alpha 3(\square), \alpha 4(\mathbf{\square}), \alpha 5(\square), \alpha 6$ (目), and $\alpha \mathrm{V}(\square)$ antibodies.

Figure 7. A ERK phosphorylation of cells cultured on dishes coated with $\mathrm{PnF}$ and the derivatives. *, $p<0.05$; significant against PnF. B Westernblot image of ERK phosphorylation of cells. Lane \# 1 PnF, \# 2 PnF-N1, \# 3 PnF-N3, \# 4 PnF-N4, \#5 PnF-COOH, \# 6 PnF-SO3H, \# 7collagen, \# 8 fibronectin

Figure 8. Proliferation of cells on dishes coated with PnF, PnF-derivatives, fibronectin, and collagen for $5(\square), 12(\square)$, and 15 ( $)$ days incubation. The coating concentration is $10 \mu \mathrm{g} / \mathrm{ml}$. $*, p<0.05$; significant difference between the two groups. 
Table 1. Conformational information of PnF and the derivatives.

\begin{tabular}{|c|c|c|c|c|c|}
\hline & \multirow[b]{2}{*}{ Percentage introduced } & \multicolumn{4}{|c|}{ Conformation $(\%)$} \\
\hline & & $\alpha$-helix & $\beta$-sheet & $\beta$-turn & radomcoil \\
\hline $\mathrm{PnF}$ & 0 & 0 & 30 & 20 & 50 \\
\hline PnF-N1 & 15 & 0 & 1 & 32 & 67 \\
\hline PnF-N3 & 26 & 0 & 0 & 29 & 71 \\
\hline PnF-N4 & 20 & 0 & 0 & 19 & 81 \\
\hline PnF-COOH & 22 & 0 & 7 & 33 & 61 \\
\hline $\mathrm{PnF}-\mathrm{SO}_{3} \mathrm{H}$ & 28 & 0 & 6 & 33 & 61 \\
\hline
\end{tabular}

Table 2. The affinity of PnF and the derivatives for integrins.

\begin{tabular}{lcccccc}
\hline \multicolumn{5}{c}{ Percent decrease in the number of cells attached by } & \multicolumn{5}{c}{ blocking with antibody against } \\
\cline { 2 - 7 } & $\alpha 2$ & $\alpha 3$ & $\alpha 4$ & $\alpha 5$ & $\alpha 6$ & $\alpha \mathrm{V}$ \\
\hline $\mathrm{PnF}$ & $9.3 \pm 2.7^{\mathrm{a})}$ & $0 \pm 5.0$ & $42 \pm 8.5$ & $17 \pm 6.9$ & $8.7 \pm 2.3$ & $0 \pm 0.75$ \\
$\mathrm{PnF}-\mathrm{N} 1$ & $14 \pm 9.4$ & $0 \pm 4.3$ & $18 \pm 4.2$ & $32 \pm 8.5$ & $39 \pm 4.8$ & $0 \pm 5.1$ \\
$\mathrm{PnF}-\mathrm{N} 3$ & $23 \pm 15$ & $3.1 \pm 1.7$ & $11 \pm 5.8$ & $19 \pm 5.4$ & $44 \pm 7.7$ & $0 \pm 3.4$ \\
$\mathrm{PnF}-\mathrm{N} 4$ & $13 \pm 3.8$ & $0 \pm 2.5$ & $2.0 \pm 4.7$ & $6.0 \pm 3.4$ & $24 \pm 3.6$ & $4.0 \pm 2.6$ \\
PnF-COOH & $13 \pm 9.3$ & $2.6 \pm 1.5$ & $38 \pm 8.1$ & $33 \pm 8.7$ & $13 \pm 5.2$ & $14 \pm 1.5$ \\
PnF-SO $_{3} \mathrm{H}$ & $2.5 \pm 0.72$ & $0 \pm 2.2$ & $0 \pm 4.5$ & $18 \pm 4.5$ & $0 \pm 1.3$ & $14 \pm 2.1$ \\
Fibronectin & $4.7 \pm 3.8$ & $0 \pm 3.2$ & $34 \pm 8.0$ & $0 \pm 4.2$ & $35 \pm 8.5$ & $0 \pm 3.2$ \\
Collagen & $46 \pm 6.3$ & $2.2 \pm 5.7$ & $0.14 \pm 9.7$ & $0 \pm 6.6$ & $9.8 \pm 4.1$ & $2.2 \pm 5.7$ \\
\hline
\end{tabular}

a) The percentage is calculated when $100 \%$ is defined for the number of cells attached without the antibody treatment. 
Figure 1.

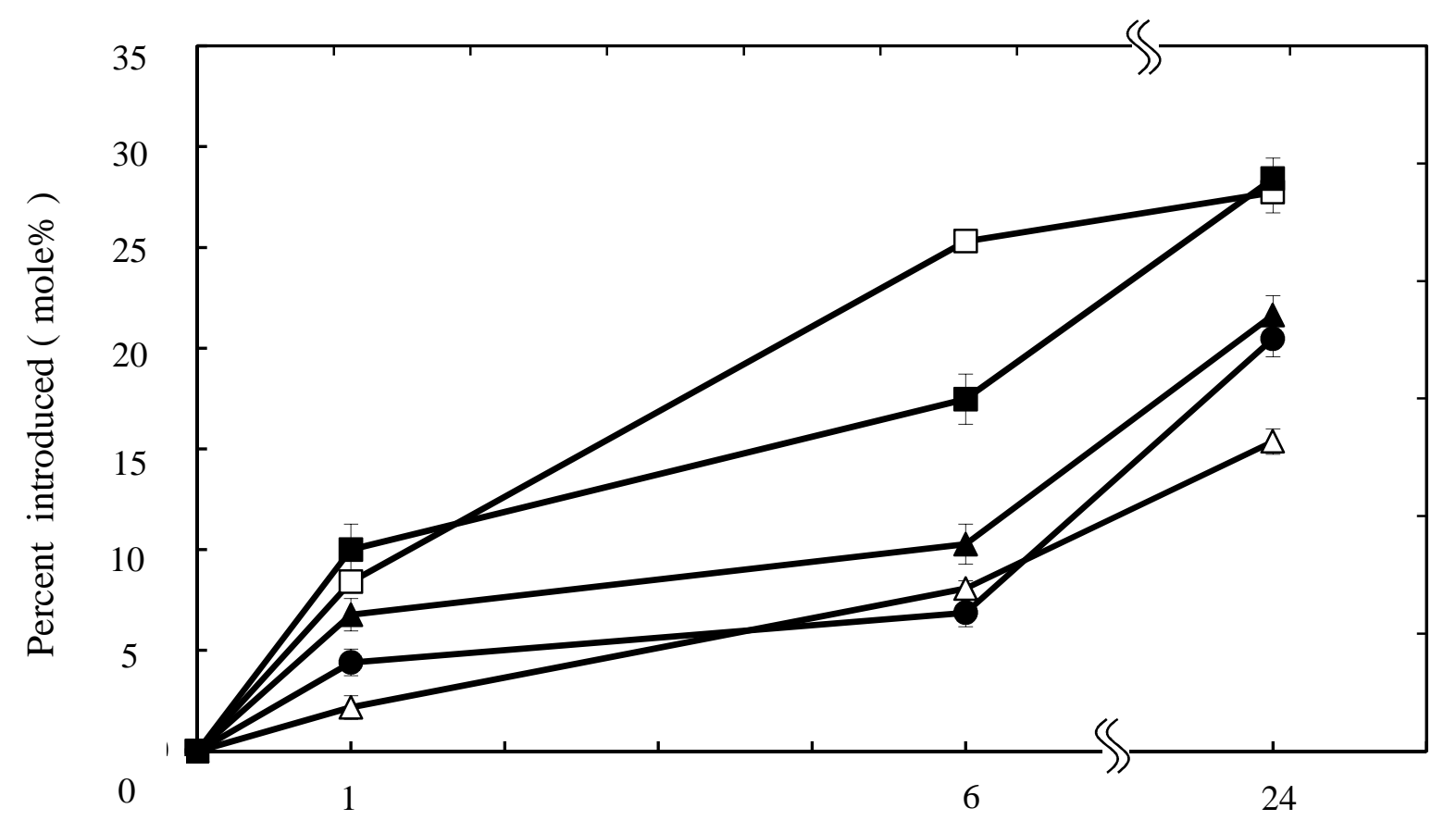

Time ( hr ) 
Figure 2.

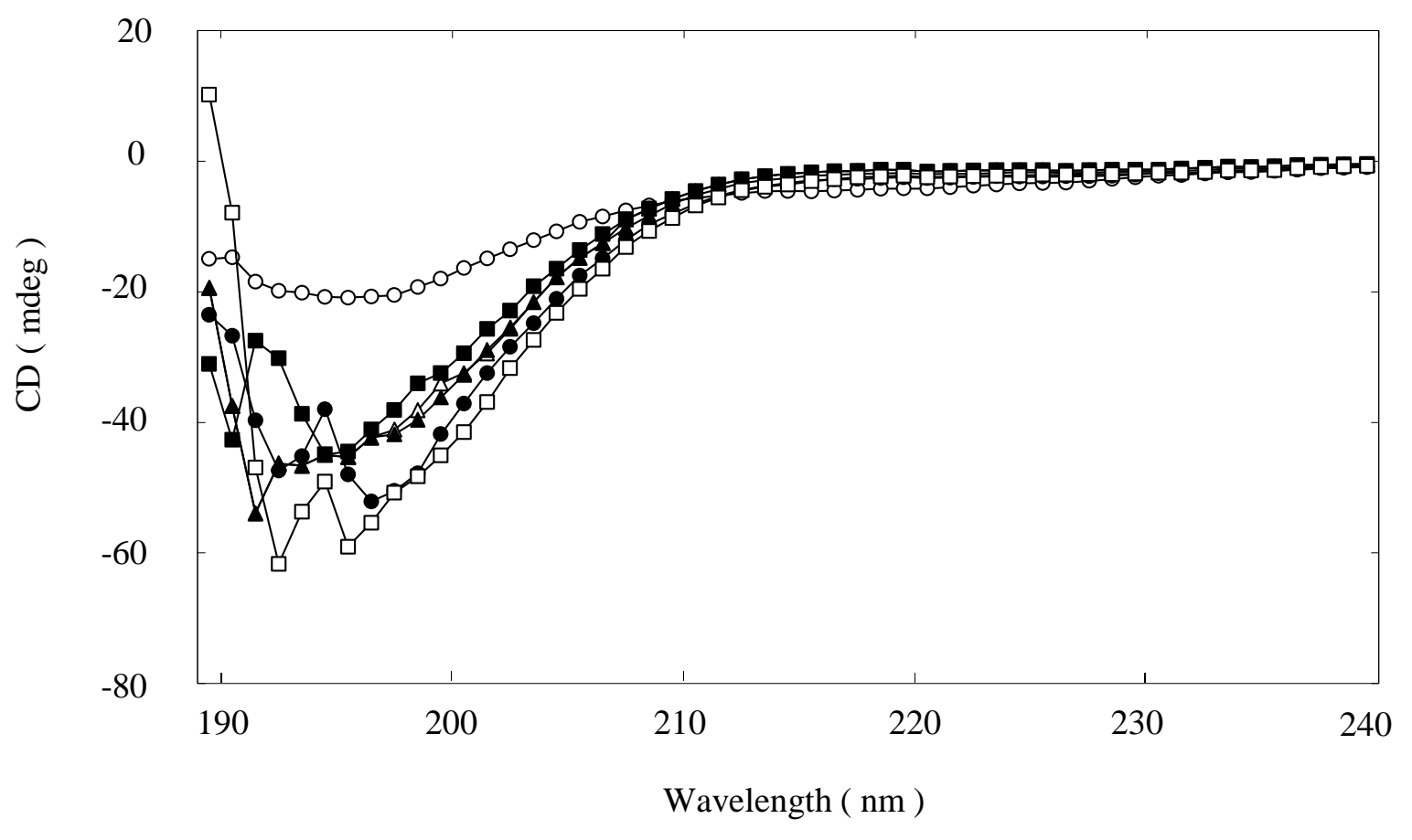


Figure 3.

A

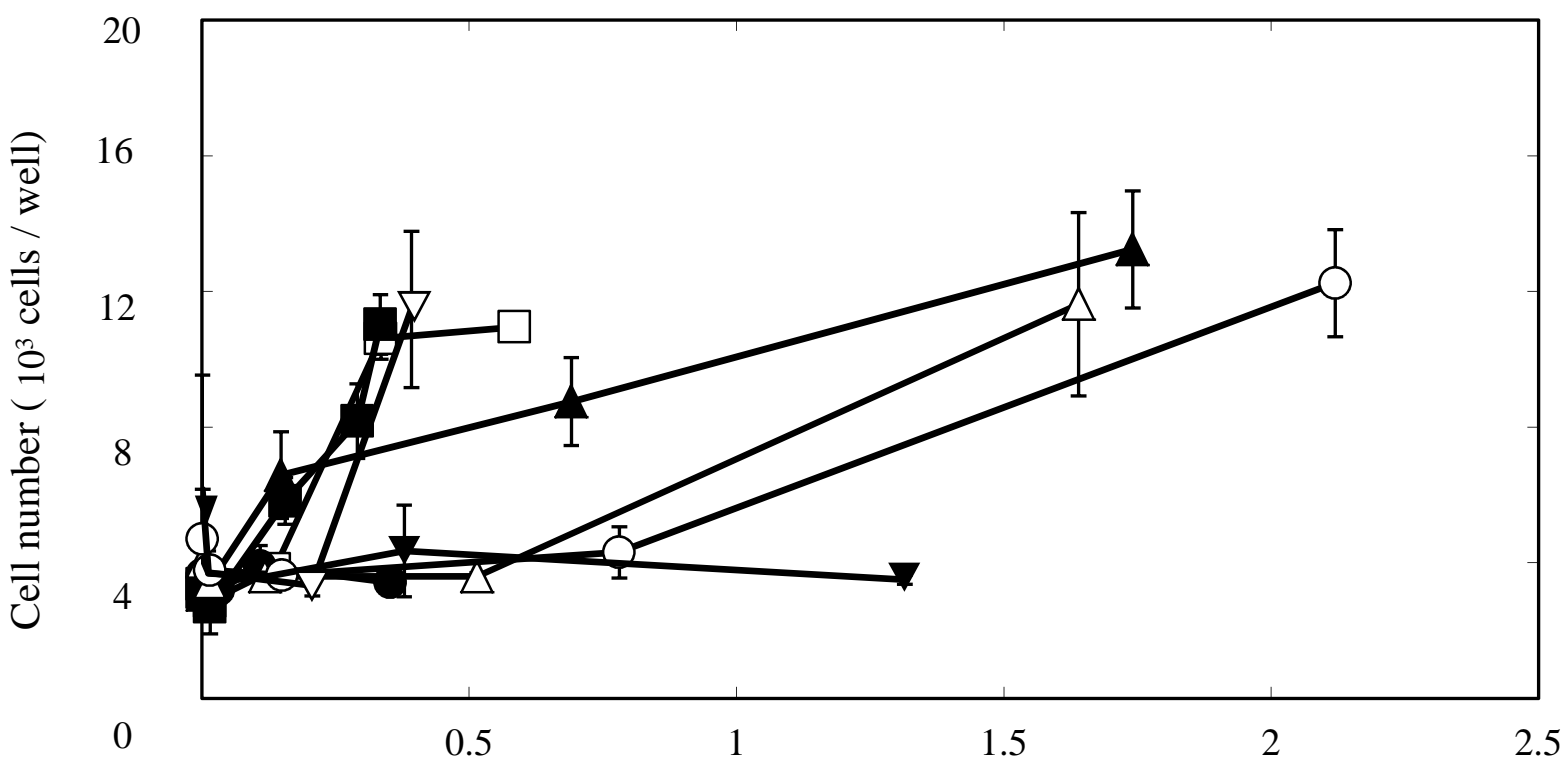

Amount of adsorption ( $\mu \mathrm{g} /$ well )

B

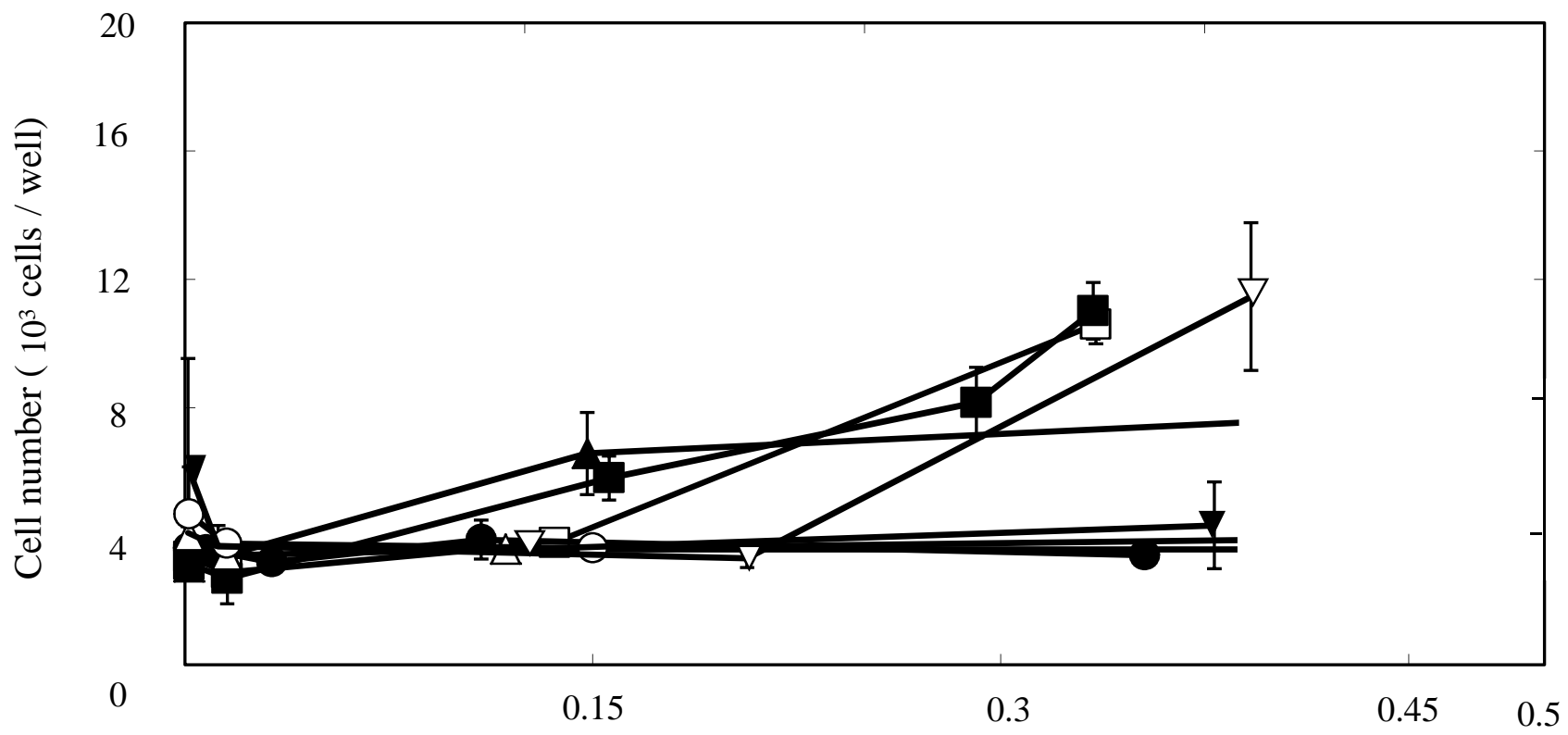

Amount of adsorption ( $\mu \mathrm{g} /$ well ) 
C

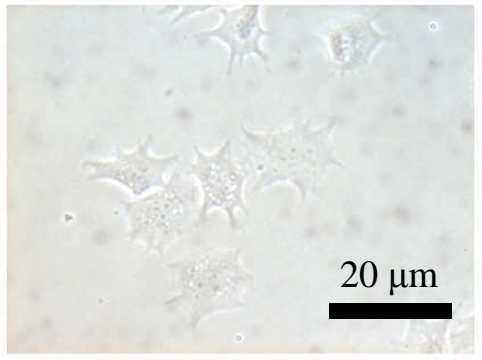

PnF

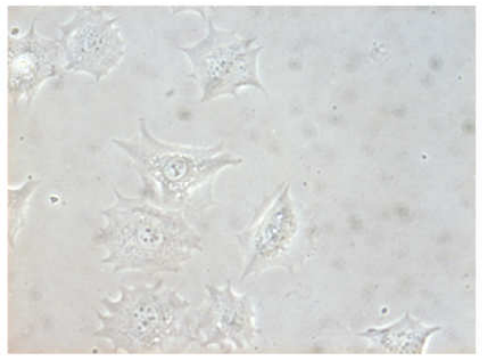

PnF-N4

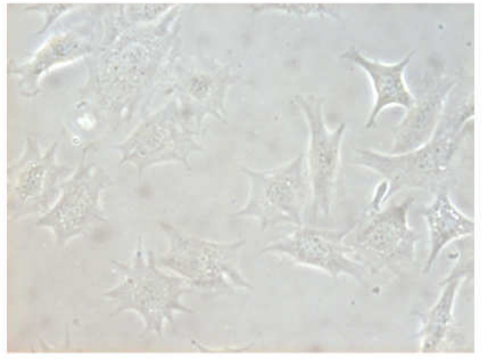

Fibronectin

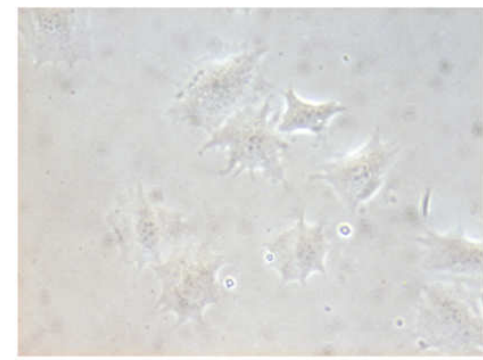

PnF-N1

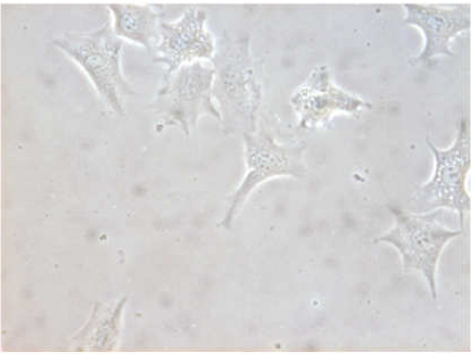

PnF-COOH

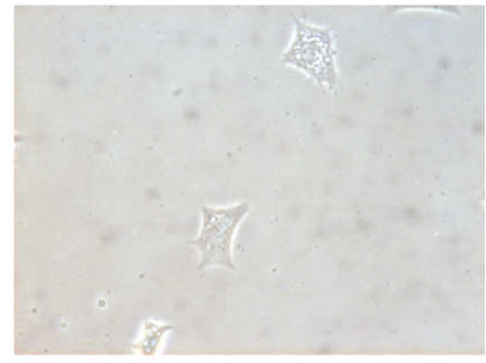

Collagen

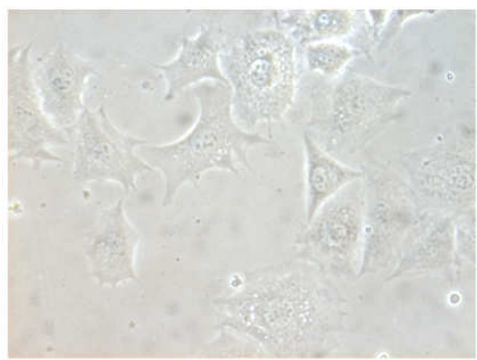

PnF-N3

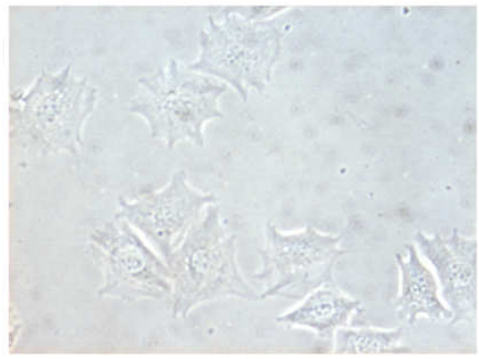

$\mathrm{PnF}-\mathrm{SO}_{3} \mathrm{H}$ 
Figure 4.

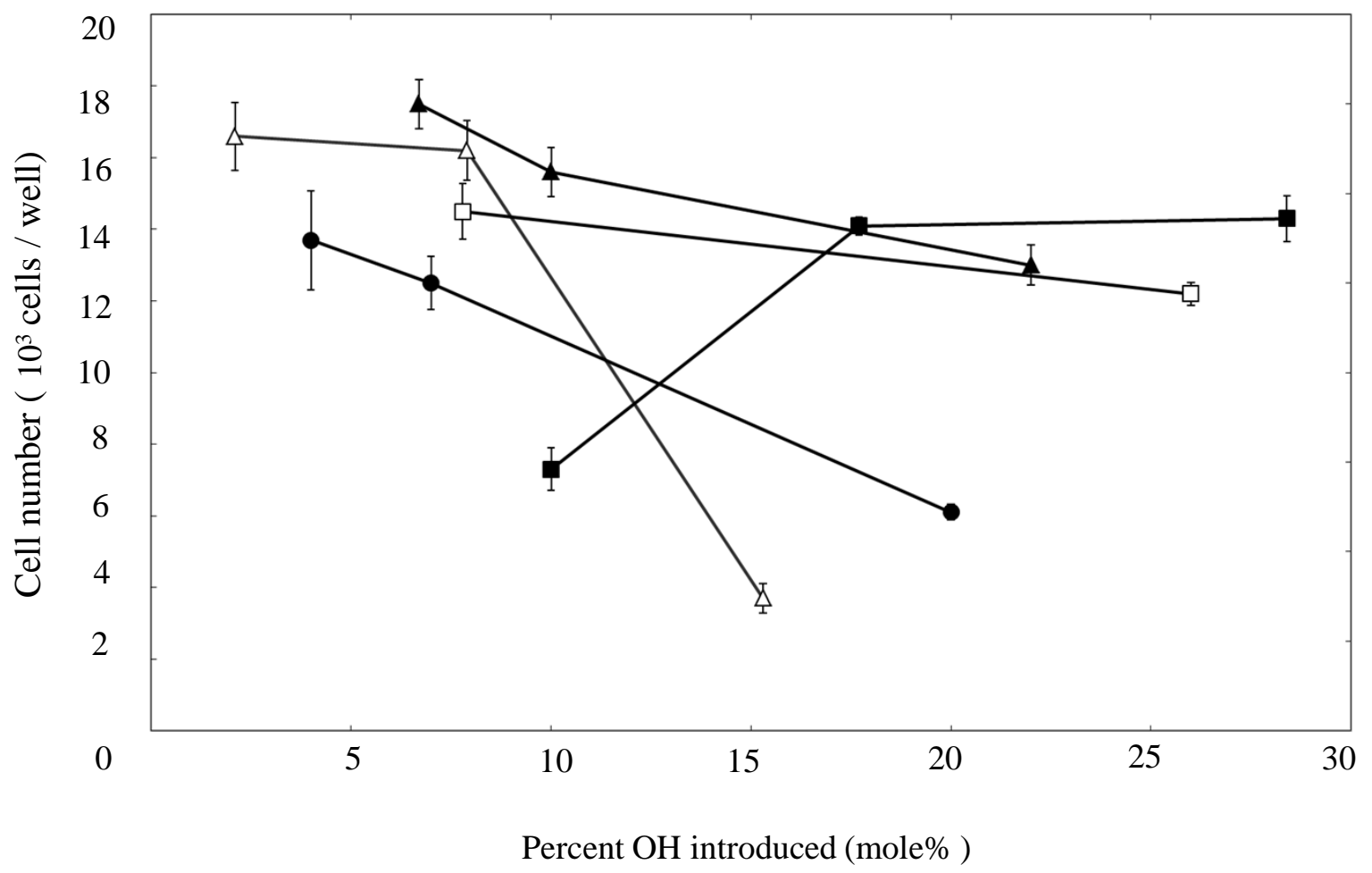


Figure 5.

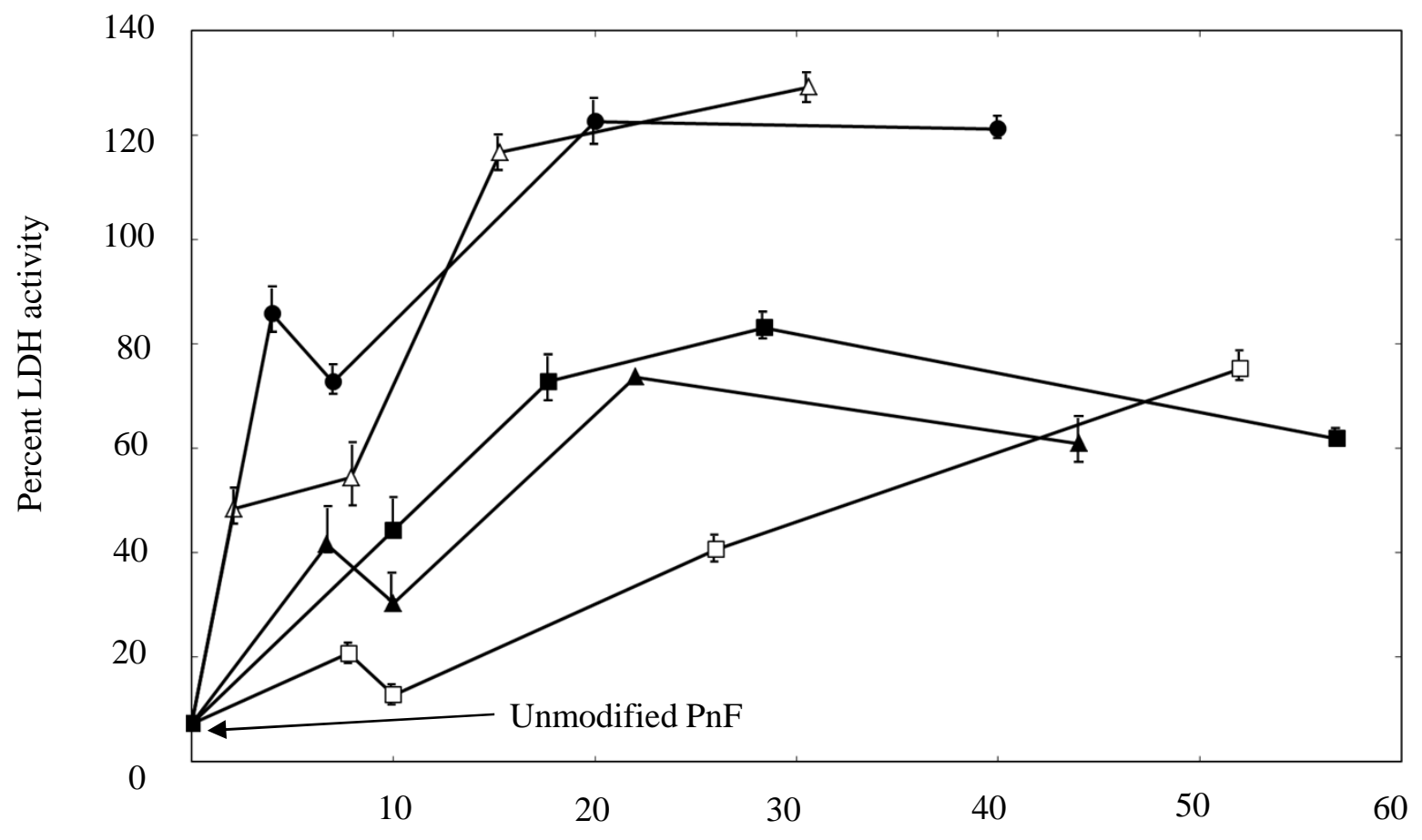

Percent $\mathrm{OH}$ introduced (mole\% ) 
Figure 6.

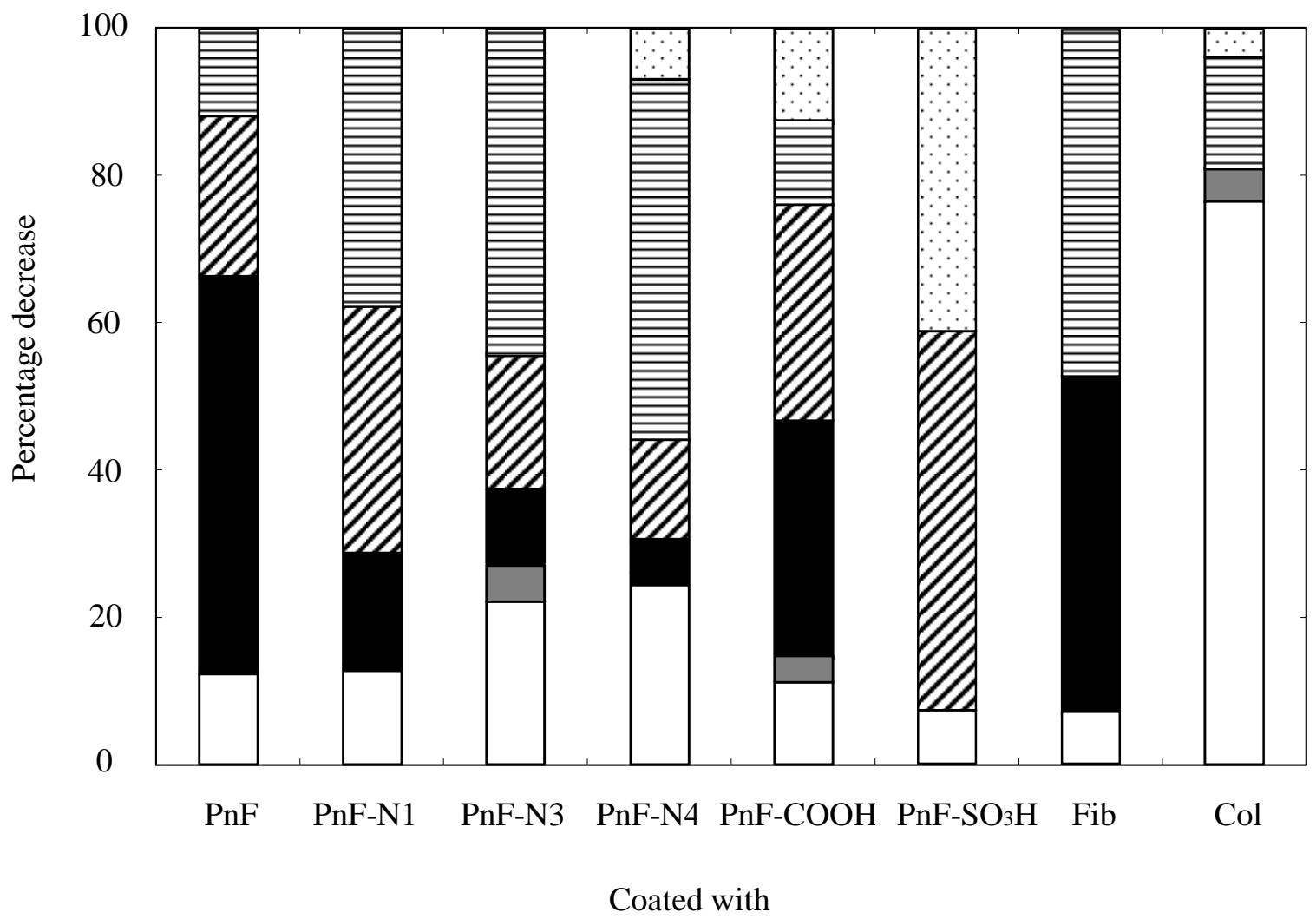


Figure 7.

A

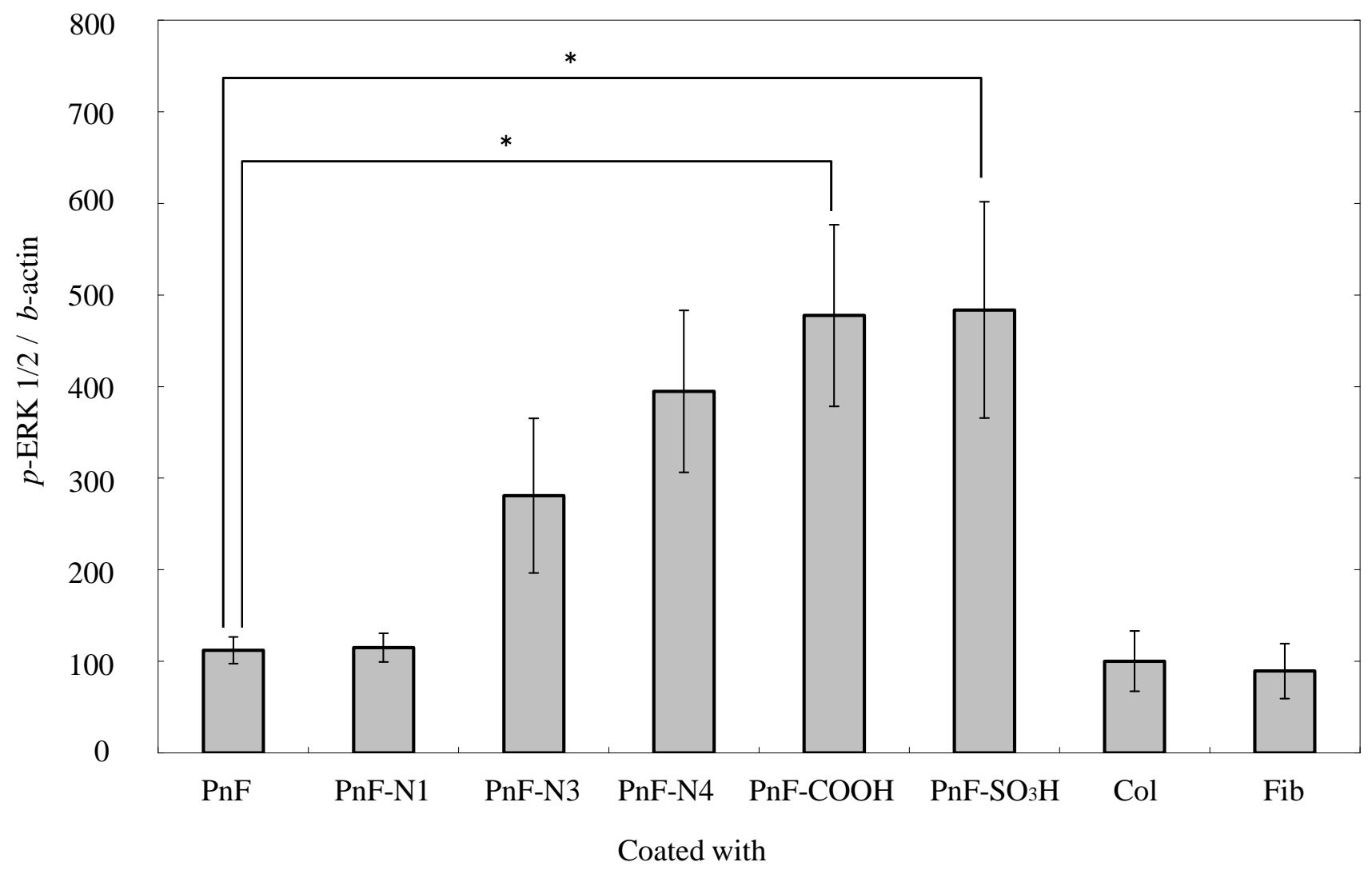

B

p-ERK 1/2

$b$-actin

lane \#

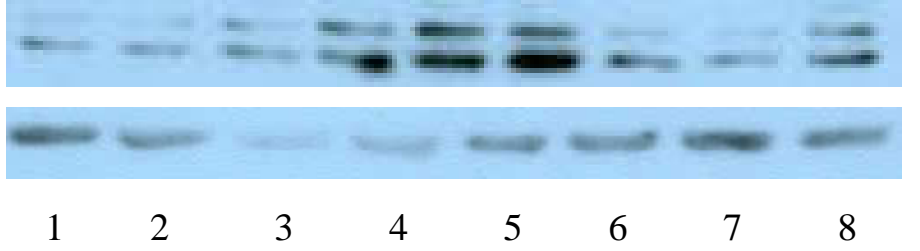


Figure 8.

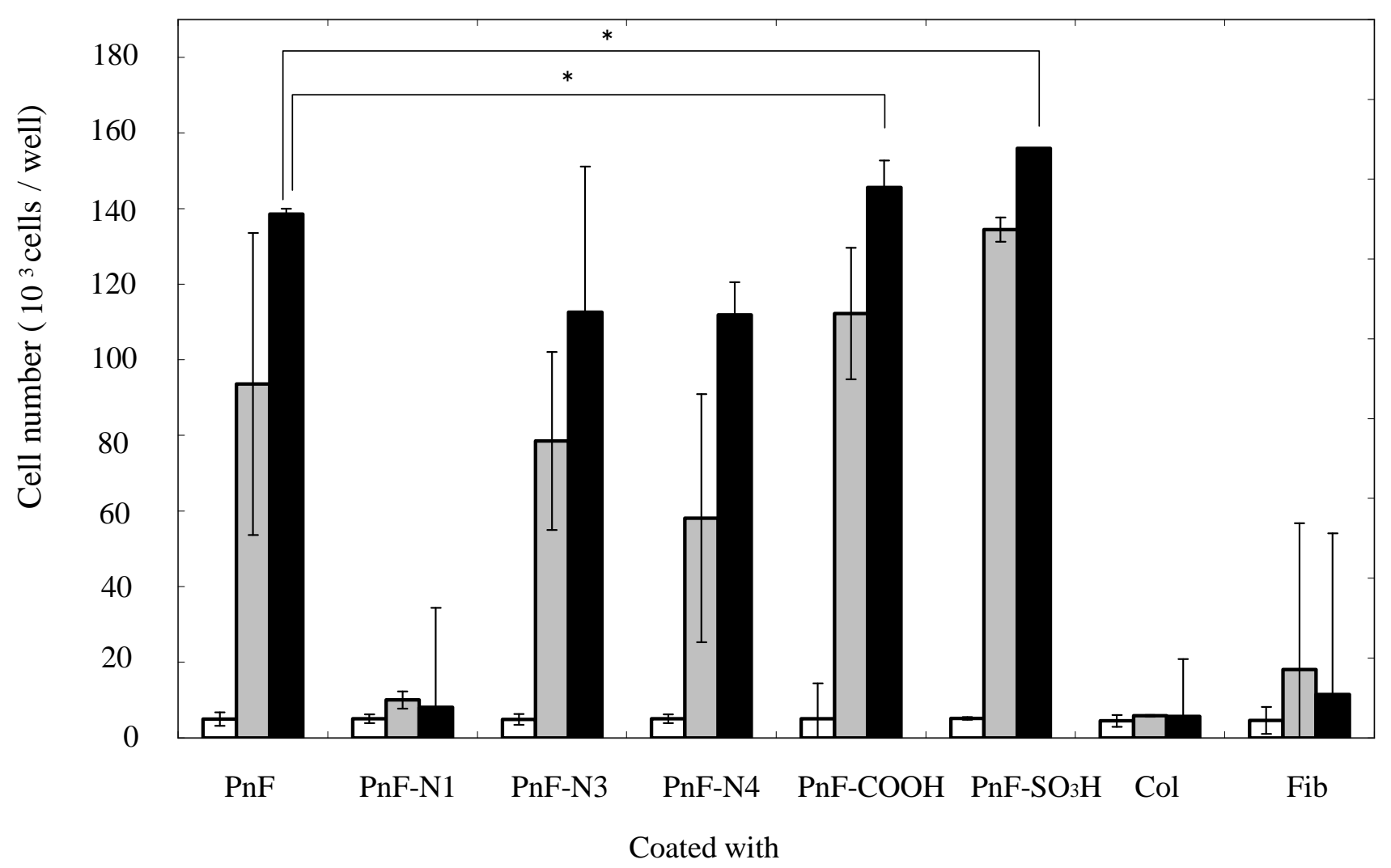

